\title{
РЕФЕРАТИ СТАТЕЙ
}

\section{Theriologia Ukrainica, 20 (2020): 3-9}

Макропросторова структура та біорізноманіття угруповань видів рукокрилих (Chiroptera) в Лісостеповому середовищі існування. - А. А. Білушенко. - Досліджено 13 видів рукокрилих, семи родів родини Vespertilionidae в умовах Центрального лісостепу України (Myotis nattereri, M. daubentonii, M. dasycneme, Barbastella barbastellus, Plecotus auritus, Pl. austriacus, Pipistrellus pygmaeus, P. kuhlii, P. nathusii, Nyctalus noctula, N. leisleri, Vespertilio murinus та Eptesicus serotinus). В основу методології покладені дані десятирічних досліджень (2007-2018) території Центрального Лісостепу (Україна - Черкаська, Кіровоградська та Київська області). Матеріал зібрано в 23 пунктах досліджень. Всього пройдено більш ніж 680 км обстежень території. Видовий склад рукокрилих визначених місць існування встановлено по ходу фауністичних, стаціонарних досліджень. Бета-різноманіття визначали шляхом оцінки видового багатства (альфа-різноманіття) при переході одного типу ландшафту до іншого, а також шляхом порівняння видового складу угруповань в різних типах місцевості. Для порівняння видового біорізноманіття було виділено п'ять типів місцевості: ліс (W), населені пункти - міста й селища (T-W), поля й лісосмуги (F-W), біляводні простори $(\mathrm{A}-\mathrm{W})$ та лісопаркові території (WP). Аналіз місць знахідок рукокрилих та характер їх біотопного розподілу показав, що більшість видів приурочені до заплавних ділянок з деревною рослинністю, де було відмічено максимальну кількість видів (біляводні простори (A-W) та лісопаркові території (W-P)). Досить високе різноманіття, також відмічене для населених пунктів (T-W). За показником рясності, помітне зниження індексу різноманіття відбувається при переході від зони біляводних типів просторів до полів та лісосмуг. За характером відмінностей груп місцевих видів рукокрилих відносно просторового розподілу, проведений аналіз дозволив виділити чотири групи. До першої групи відносяться види, об'єднані просторами відкритого типу (N. noctula, N. leisleri). До другої групи: V. murinus, E. serotinus, P. pygmaeus та P. kuhlii, яких досить важко приурочити до якогось конкретного типу просторів. До третьої групи відносяться види, які об'єднані просторами закритого типу (M. nattereri, M. daubentonii, B. barbastellus, Plecotus). До четвертої групи відноситься досить рідкісний на території дослідження вид - M. dasycneте, що прив'язаний до стоячих або ж з повільною течією водойм.

Ключові слова: рукокрилі, Лісостеп, угрупування, Chiroptera.

Адреса для зв’язку: Черкаський міський зоологічний парк «Рошен», м. Черкаси, вул. Смілянська, 132; e-mail: bat_cherkassy@ukr.net

\section{Theriologia Ukrainica, 20 (2020): 10-28}

Список ссавців України 2020: доповнення та уточнення. - I. Загороднюк, С. Харчук. — Розглянуто загальні питання «таксономічного моніторингу» теріофауни України, включно 3 поточними змінами та уточненнями у знаннях про видовий склад фауни, про таксономічні ранги представлених у ній видів і надвидових груп та актуальні наукові й вернакулярні (українські) назви. Представлено аналітичні довідки та коментарі щодо рангів і назв 24 таксонів або таксономічних груп, зокрема: 6 - Glires non-Muroidae, 7 - Muroidae, 5 - Chiroptera, 2 - Carnivora, 4 - Ungulata. Здебільшого зміни стосуються рангів таксонів (надто рід/підрід або родина/підродина), дещо меншою мірою - наукових назв і лише кілька - українських назв. Усі зміни аналізуються як уточнення до контрольного списку, затвердженого Українським теріологічним товариством (УТТ) i опублікованого 2012 року у «Віснику ННПМ» як базовій установі УТТ. Зокрема, у цій публікації визнається реальність як таксонів і правильність використання наукових видових назв Spalax graecus, Spalax arenarius, Apodemus (Sylvaemus) tauricus, Myotis aurascens; українських вернакулярних назв «гіпсуг» (для Hypsugo) і «сайга» (для Saiga); наукових родових назв Myodes (нориця) і Alexandromys (шапарка); родинного рангу довгокрилових (Miniopteridae); наукову назву для хом'ячка сірого залишено (Cricetulus migratorius). Приймається на підставі нових публікацій і тенденцій розвитку класифікацій: 1) нове розуміння обсягу та назви виду Spermophilus planicola (ховрах сірий), а також виду Pipistrellus lepidus (нетопир білосмугий); підтвердження родинного статусу мишівкових, однак із новою науковою назвою Sminthidae; коректність наукових назв Neogale vison (візон річковий), Ovis gmelini (муфлон); 2) уточнення української вернакулярної назви «молосові» для Molossidae; 3) рід нутрія (Myocastor) віднесено до родини щетинцевих (Echimyidae), а роди полівок (Microtus), нориць (Myodes) і щурів (Arvicola) — до родини хом'якових (Cricetidae); 4) зниження рангів кількох таксонів, зокрема Arvicolidae до підродини Arvicolinae (в межах Cricetidae), Allactagidae до підродини Allactaginae (у складі родини Dipodidae), Terricola до підроду в межах роду Microtus (s. 1.), Bison до підроду в межах роду Bos (звідки зубр - Bos bonasus), 5) збереження родового рангу Sylvaemus на рівні 3 родом Apodemus. Розглянуто тенденції подальших змін контрольних списків і потреби узгодження з базовими контрольними списками й адаптації «тематичних» списків, таких, як «червоні списки» національного або регіонального рівнів, списки мисливської фауни, списки видів у додатках до різних міжнародних угод (напр. SITES, Bern Convention, EUROBATs тощо). 
Ключов і слова: ссавці, таксономічна ревізія, номенклатура, біорізноманіття, Україна.

Адреса для зв'язку: Ігор Загороднюк; Національний науково-природничий музей, НАН України; вул. Б. Хмельницького 15, Київ, 01030 Україна; e-mail: zoozag@ukr.net; orcid: 0000-0002-0523-133X

\section{Theriologia Ukrainica, 20 (2020): 29-38}

Видовий склад мікромамалій основних біотопів околиць смт Коломак (Харківщина). - О. Марковська. - Дослідження видового складу та біотопних преференцій дрібних ссавців в околицях смт Коломак проводили на протязі чотирьох років (2017-2020 рр.). За період дослідження було виявлено 9 видів мишоподібних гризунів та три види комахоїдних. 3 теоретично очікуваних видів, які вже відомі для цього району, не трапилися хом'ячок сірий, норик підземний та шапарка сибірська. В околицях смт Коломак досліджено 11 біотопів в межах кленово-липової діброви, агроценозів, суходільних та заплавних луків, розташованих по берегам ставу та в яруго-балковій системі. Перший рік досліджень припав на рік високої чисельності (2017р.) і тоді відразу було зафіксовано 9 видів, але нечисленні види, такі як білозубка мала, мідиця мала та мишка лучна, були виявлені в роки з невеликою відносною чисельністю дрібних ссавців. До постійно домінуючих видів у відловах можна віднести норицю руду, мишака жовтогрудого та мишака уральського. За результатами відлову 2017 р. виявився роком високої відносної чисельності дрібних ссавців, 2018 р. - мінімальної, 2019 та 2020 рр. - середньої відносної чисельності. В лісових біотопах за період дослідження зафіксовано 6 видів (житник пасистий, мишак жовтогрудий, мишак уральський, нориця руда, мідиця звичайна та соня лісова), в екотонах з заплавними біотопами - 8 видів (житник пасистий, мишак європейський, мишак уральський, миша хатня, мишка лучна, нориця руда, полівка лучна та мідиця звичайна), також 4 види (миша хатня, мишак європейський, мишак уральський та полівка лучна) трапляється неподалік людських садиб. Загалом, до біотопів 3 найбільшим видовим різноманіттям та кількістю відловлених особин належать екотони суходільних та заплавних лук. В роки високої чисельності збільшується як різноманіття видів, так і кількість зловлених особин в діброві та в екотонах поблизу водойм. Варто відзначити, що на вирубці за два роки (2019-2020 pр.) лише влітку 2020 року трапилася нориця руда, до того там не було зареєстровано жодної особини, хоча на цій місцевості спостерігається доволі щільний бур'янистий трав'яний покрив та подекуди відріс чагарниковий ярус, також вирубка оточена з усіх боків дібровою.

Ключові слова: дрібні ссавці, відносна чисельність, біотопна преференція, видовий склад, багаторічний моніторинг.

Адреса для зв'язку: Оксана Марковська; Харківський національний університет імені В. Н. Каразіна, Площа Свободи 4, Харків, 61022 Україна; e-mail: ksenia.markovskaia@gmail.com; orcid: 0000-0002-2573-4524

\section{Theriologia Ukrainica, 20 (2020): 39-45}

Великі травоїдні в обмежених екосистемах: оцінка водних джерел за постійними стежками на косі Бирючий острів. - М. Ползик. - Популяція тварин, що постійно проживає на певній території не тільки пристосовується до умов навколишнього середовища, але змінює його внаслідок своєї діяльності. Постійне переміщення тварин між цінними ресурсами на певній території утворює систему постійних троп. Їх дослідження $\epsilon$ цінним джерелом інформації для вирішення задач спрямованого формування екосистем, організації охорони та раціонального використання території. Територія нашого дослідження - Бирючий острів $\epsilon$ косою намивного типу з піску та черепашнику. Острів вкриває різноманітна водно-болотяна, лучна та степова рослинність, наявна ділянка штучного лісу. Природні джерела прісної води - відсутні. 3 1950-х років тут мешкають декілька видів великих травоїдних: благородні олені, лані, кулани та здичавілі коні. Для забезпечення тварин прісною водою в тут були створені штучні водойми. 3 метою визначення інтенсивності використання водопоїв коси Бирючий острів, нами проведена їх оцінка на основі аналізу системи постійних стежок. В роботі використані матеріали зібрані в 2014-2018 рр. під час польових досліджень та супутникові зображення місцевості. В період дослідження загальна чисельність копитних коливалась в межах 2700-3400 особин. Для оцінки інтенсивності використання водопоїв визначали кількість та напрям постійних стежок, оцінювали відстань до інших джерел, місць сховищ або кормових ресурсів, мікрорельєф та кліматичні особливості, антропогенні фактори. Дані зібрані для 31 штучного джерела. 3'ясовано, що постійні стежки можуть поширюватися від джерела у 25 напрямках. Проте частіше вони сконцентровані в північному та північно-східному напрямках. Це пов'язано з розташуванням на півночі найбільш захищеної від погодних умов території острова - очеретяних заростей та різноманіттям поживних кормів. Від узбережжя лиману на півночі до найближчих джерел прісної води 2,5-3 км. Від водопою тропи розходяться в середньому на 3,4 км². Аналіз системи стежок показав, що 45 \% водопоїв інтенсивно використовуються копитними, $22 \%$ - не мають слідів постійного використання.

Ключові слова: великі травоїдні, стежки, коса Бирючий острів, поведінка тварин.

Адреса для зв'язку: Марія Ползик; Запорізький національний університет; вул. Гоголя, 62; e-mail: polzikm@gmail.com; orcid: 0000-0002-5403-0542 


\section{Theriologia Ukrainica, 20 (2020): 46-57}

Шакал звичайний (Canis aureus) у Національному природному парку «Тузлівські лимани». І. Русєв. - Наведені дані щодо появи, просторового розподілу та особливості екології шакала звичайного у природних екосистемах національного природного парку «Тузлівські лимани». Визначено приблизний кількісний склад цих тварин, а також надана оцінка впливу шакала звичайного на місцеву фауну. За 20 років 3 того часу, коли були зареєстровані перші шакали на узбережжі Українського Причорномор'я, можна констатувати, що шакал добре освоївся в природних екосистемах НПП «Тузлівські лимани». Для цього виду хижаків в Парку на степових ділянках, причорноморському пересипу та штучному Лебедівському лісі, наявні хороші захисні та кормові умови. Для виведення цуценят, окрім відкритих природних біотопів, особливо очеретяних заростей водно-болотних угідь, хмизу в Лебедівському лісу, шакал використовує вириті ним самим норі. На території Парку в даний час просторово розміщено не менше п’яти територіальних угруповань шакала. Кількість виводків і розмірів зграй шакала флуктуює в залежності від кліматичних умов року та рівня води в лиманах, що обумовлює доступність їжі та характер полювання. Чисельність шакала на території Парку та його прилеглих територій у 2020 році була вища ніж в період, коли рівень води в лиманах був вищий, тобто, вище ніж 5 років тому, і сягала біля 150 особин. Щільність населення шакала в Парку не більш 10 особин на 1000 га. Протягом п'яти років спостережень з 2015 по 2020 pp. чисельність шакала незначно зростала завдяки розширенню суходолу Тузлівських лиманів, де раніше були мілини, а також завдяки зростанню площі піщаного пересипу і доступності всіх острівних систем, на яких раніше гніздились птахи і таким чином зростанню площі угідь, привабливих для полювання шакалів. На території Парку не спостерігається різка тенденція до росту чисельності шакала звичайного. Але, зважаючи на ймовірність захворювання та розповсюдження сказу цим видом хижаків, на окремих рекреаційних ділянках потрібно використовувати антирабічну вакцину для пероральної імунізації м’ясоїдних тварин проти сказу, що і було зроблено в вересні 2020 року на ділянці Парку в урочищі «Лебедівський ліс».

Ключові слова: національній природний парк, «Тузлівські лимани», шакал, розмноження, чисельність, щільність.

Адреса для зв'язку: Іван Русєв; національний природний парк «Тузлівські лимани», 2, вул. Партизанська, Татарбунари, Одеська область, 68100 Україна; e-mail: rusevivan@ukr.net; orcid: 0000-0003-4993-3672

\section{Theriologia Ukrainica, 20 (2020): 58-66}

Генетичне різноманіття вільної популяції коней Пржевальського в Чорнобильській зони відчуження. Е. Е. Хейдорова, К. В. Гомель, М. Е. Никифоров, А. В. Шпак, В. Ч. Домбровський, М. С. Шквиря, П. Шліхтинг, Д. Бізлі, Д. О. Вишневський, С. Б. Яковлєв. - Ця робота спрямована на оцінку генетичної різноманітності, генетичного статусу і ступеня гібридизації з домашньою конем у вільній популяції коней Пржевальського в умовах природної свободи на території зони відчуження Чорнобильської АЕС в межах Білорусі та України. Обсяг вибірки склав 12 особин (10 з Білорусі та 2 з України). Як генетичні маркери для вивчення генетичного статусу популяції коней Пржевальського вибрано мікросателіти (n = 10), рекомендовані Міжнародним товариством генетики тварин (ISAG) для дослідження генетичної різноманітності і родоводу коней. В результаті отриманих даних фрагментного аналізу на базі використаної мікросателітної панелі встановлено, що дві особини з Білорусі не несуть алельних варіантів, характерних для коня Пржевальського. Для більшості інших досліджених особин коня Пржевальського відзначено присутність діагностично цінних алельних варіантів. Аналіз на наявність в демографічній історії дослідженої популяції коней Пржевальського ознак різкого зниження чисельності не виявлено. Розглянута популяція коней Пржевальського має гетерогенну генетичну структуру 3 наявністю ознак інбридингу $(0,21 \%)$ і характеризується помірним рівнем генетичного різноманіття $(\mathrm{He}=0,63)$ і алельного багатства $(5,15)$, має 16 унікальних алелів за двома мікросателітними локусами і цінні алелі за локусами HMS3 і HMS7 (46,4 і 67,9 \% специфічних для коней Пржевальського алелей відповідно). Оцінка наявності генетичної структурованості проводилася за допомогою байссівського аналізу і факторного аналізу відповідності (FCA). Байєсівський аналіз і факторний аналіз відповідності показали наявність внутрішньо-популяційного генетичного підрозділу для обстеженої популяції. Беручи до уваги отримані показники генетичного різноманіття, можна говорити про відносно сприятливий статус коней Пржевальського в зоні відчуження ЧАЕС $з$ хорошим потенціалом для тривалого існування популяції виду в дикій природі. 3 метою мінімізації ефектів інбридингу і ризику зниження генетичної різноманітності в даній популяції коней Пржевальського, а також для підвищення цінності цієї вільної групи для збереження генофонду виду в цілому, необхідно провести детальний генетичний моніторинг стану поголів'я, а також розробити регіональний план управління популяцією, включаючи заходи, які будуть мінімізувати можливість подальшої гібридизації диких коней зі свійськими.

Ключові слова: Кінь Пржевальського, Чорнобильська зона відчуження, мікросателіти, генетична структуpa.

Адреса для зв'язку: А. В. Шпак; Науково-виробничий центр НАН Білорусі з біоресурсів; вул. Академічна, 27, Мінськ, 220072 Республіка Білорусь; e-mail: shpak.dvergr@ gmail.com, orcid: 0000-0002-0563-9271 


\section{Theriologia Ukrainica, 20 (2020): 67-72}

Мишоподібні гризуни урочища Червоне (Дністровський каньйон): особливості видового складу та структури угруповань. - О. Штик, 3. Мамчур. - Проведено аналіз угруповань мишоподібних гризунів Національного природного парку «Дністровський каньйон» на прикладі урочища Червоне. Опрацьовано результати досліджень за 2017-2018 pр. (літні та осінні обліки), проведених у 4 біотопах НПП. Для дослідження фауни мишоподібних гризунів ми застосували методику обліку пастко-лініями, використовуючи живоловки фабричного зразка. Згідно з методикою, пастки розставляли в межах однорідного біотопу і закладали чотири пробні ділянки. Біотопи, на яких були проведені дослідження класифіковані згідно з Національним каталогом біотопів України. Видовий склад мишоподібних гризунів вивчали в межах чотирьох біотопів поблизу Джуринського водоспаду: у грабовому та сосновому лісах, у заплавній ділянці річки Джурин та на пасовищі. Під час дослідження фауни мишоподібних гризунів відловили 75 особин протягом 800 пастко-днів. Встановлено, що на досліджуваній території нараховується 6 видів мишоподібних гризунів: Sylvaemus tauricus L., Sylvaemus sylvaticus L., Apodemus agrarius Pallas, Micromys minutus L., Myodes glareolus Schreber та Microtus arvalis Pallas. Найпоширенішим видом мишоподібних гризунів є Sylvaemus tauricus - 23 особини (31\%). Частка трапляння інших видів є така: Apodemus agrarius (28\%), Sylvaemus sylvaticus (17\%), Myodes glareolus (16\%), Microtus arvalis (7 \%), Micromys minutus (1\%). Чисельність тварин влітку є нижчою, ніж восени, що, ймовірно спричинено антропогенним тиском, присутнім на досліджуваній території. Також ми вивчали статевовікову структуру угруповань мишоподібних гризунів. Виявили, що 40375 особин були чоловічої статі, а 35 особин - жіночої. Крім того 63 особини були дорослими (ad.), а 12 - ювенільними (juv.), тобто молодими. Для узагальнення отриманих даним зробили прорахунок особин на 100 пастко-днів і виявили, що значення коливаються в межах від майже 3 особин/100 п.д. (для виду Sylvaemus tauricus) до 0,125 ос/100 п.д. (для найменш чисельного виду Micromys minutus). Відносно невелике видове різноманіття пояснюємо малою площею «островів» (окремої площі з приблизно однаковим ландшафтом) та сильно фрагментованою територією НПП «Дністровський каньйон».

Ключові слова: мишоподібні гризуни, Придністер'я, теріофауна, НПП «Дністровський каньйон».

Адреса для зв'язку: О. Штик; Львівський національний університет імені Івана Франка; вул. Грушевського, 4, Львів, 79005 Україна; e-mail: olya1235@ukr.net; orcid: 0000-0002-2913-5609

\section{Theriologia Ukrainica, 20 (2020): 73-78}

Курганщева миша (Mus spicilegus) на Західному Поділлі: експансія на лівобережжі Дністра. — О. Вікирчак. - Описано нові знахідки миші курганцевої на лівобережжі Дністра у межиріччі його приток Джурина на Нічлави (Чортківський район Тернопільської обл.). Наявність Mus spicilegus встановлювалась на основі знахідок притаманних для цього виду запасів кормів у формі характерних курганчиків, які легко виявити на місцевості і які однозначно діагностуються. До уваги бралися як поодинокі курганчики так і їх скупчення. Вказано на особливості біотопного розподілу, формування кормових запасів та ролі у трофічних ланцюгах даного виду в умовах досліджуваного регіону. Миша курганцева - один з небагатьох видів гризунів, що підтримують високу чисельність за умов інтенсивного ведення сільського господарства, що передбачає кількаразовий впродовж року механічний обробіток грунту та значний рівень використання хімічних засобів. На поширення виду, що досліджується, впливають насамперед два фактори: рівень агротехніки ведення сільськогосподарського виробництва (обробітку ріллі та догляду за посівами, якість збиральних робіт) та віддаль від ділянок, що не обробляються. Зазвичай курганцева миша заселює сільськогосподарські угіддя з низьким рівнем агрокультури (мінімальна хімізація та механічний обробіток грунту). Це землі, що виділені для ведення особистого підсобного господарства (городи) або фермерського господарства. На таких угіддях підвищена забур'яненість та втрати урожаю під час жнив, що створює багату кормову базу. Після збирання урожаю такі угіддя як правило довго не зазнають операцій з механічного обробітку грунту. У статті показано що заселення орних земель відбувається із природних чи інших необроблюваних ділянок, де зберігаються ядра популяцій. Восени за сприятливих умов, що визначені вище, приріст популяцій перекочовує на суміжні оброблювані ділянки, де формують зимові кормові запаси у вигляді характерних курганчиків. На великих за площею посівах монокультур, що обробляються великими агрофірмами, курганчики як правило відсутні. Рівень агротехнічного пресу на одну й ту ж площу коливається від року до року. Це спричинює часову нестабільність появи курганчиків. Вони зникають там, де антропогенний вплив знову став значним і з'являються у місцях, де було його послаблення. Показана роль миші курганцевої у трофічних ланцюгах та у підтриманні біорізноманітності регіону.

Ключові слова: миша курганцева, Mus spicilegus, експансія, кормові запаси, біотопи, Придністер'я.

Адреса для зв'язку: О. Вікирчак; НПП «Дністровський каньйон», вул. Степана Бандери, 5Б, м. Заліщики, Тернопільська обл., 48601 Україна; e-mail: ol_vikirchak@ukr.net; orcid: 0000-0002-2683-9213 


\section{Theriologia Ukrainica, 20 (2020): 79-90}

Мишівка південна Sicista loriger (Dipodoidea) в Криму: поширення, оселища, сезонна активність, чисельність. - І. Свстаф'єв. - Мишівка південна - рідкісний і нечисленний вид дрібних ссавців фауни Кримського півострова. Протягом XX ст. йшло поступове скорочення ії ареалу. Спочатку мишівка південна займала практично всю територію степового и передгірного Криму, а по мірі скорочення площі цілинних, не ораних та не занятих під сільське господарство земель, вид перестав зустрічатися на більшій частині півострова. Якщо в середині минулого століття вид ще реєструвався в 11 адміністративних районах, то з початку нинішнього тільки в трьох (при цьому в двох із них він вкрай нечисленний). У наш час мишівка південна існує в вигляді двох ізольованих популяцій: західної (тарханкутської) і східної (керченської), розділених одна від одної 200-ми кілометрами антропогенних ландшафтів. Обліки дрібних ссавців методом пастко-ліній, проведені упродовж останніх 40 років, мали обсяг 667,1 тис. пастко/ночей, що дозволило зловити 144 мишівки. Зібрані 16,8 тис. пелеток вухастої сови дозволили виявити кісткові рештки 56 екз. мишівки. Тарханкутська популяція нечисленна (пастками здобуто 12 екз., в пелетках ідентифіковано 39 екз.), а її ареал дуже обмежений за площею. Керченська популяція більш чисельна: пастками спіймано 132 мишівки і ще 17 особин ідентифіковано в пелетках хижих птахів; іiї ареал займає весь Керченський півострів. Дані масових багатолітніх епізоотологічних обліків показали, що частка здобутих мишівок південних в загальнокримському масштабі склала 0,21 \%, а їхня частка у степовій зоні - 0,29\%, при відносній чисельності 0,03 екз./100 пастко-ночей. Мишівки активні 3 середини квітня і до середини листопада. Пік активності приходиться на квітень коли здобуто 49,9\% звірків. Із природних ворогів, реальну загрозу чисельності виду можуть наносити: звичайна лисиця (Vulpes vulpes), а в локальних мікропопуляціях південних мишівок - вухаста сова (Asio otus), особливо в період розмноження. На нашу думку, не дивлячись на сумарну низьку чисельність мишівки в Криму та фрагментацію іï ареалу, загрози зникнення виду на півострові (особливо керченської популяції) при нинішній системі хазяйнування, немає. Для збереження популяцій мишівки на території Криму потрібне детальне вивчення ії біоекології, особливо лімітуючих факторів.

Ключові слова: мишівка південна, поширення, чисельність популяції, сезонна активність, Крим.

Адреса для зв'язку: Ігор Євстаф'єв; Кримська республіканська санітарно-епідеміологічна станція вул. Набережна 67, Сімферополь, 79005 Україна; e-mail: e-igo@ukr.net; orcid: 0000-0003-1586-8411

\section{Theriologia Ukrainica, 20 (2020): 91-104}

Поширення та мінливість мишаків групи Sylvaemus microps \& uralensis у Східній Свропі: фрагментація та клини. - I. Загороднюк. - Розглянуто таксономічну історію лісових мишей групи Apodemus microps \& Sylvaemus uralensis та історію розростання знань про їхнє поширення. Два названі номени $є$ маркерами двох ключових етапів визнання таксономічної гетерогенності Sylvaemus sylvaticus (s. str.), до складу якого їх довгий час включали. Перший з них був описаний 1952 р. з Центральної Європи, другий — на 140 років раніше (1818) з Південного Уралу. Обидва ці таксони пережили складну таксономічну історію і наразі визнані конспецифічними. Проте між ними є певні розриви, зокрема й географічні. Тут вони розглядаються як дві групи популяцій, західна (microps) та східна (uralensis). Проведено аналіз географічної мінливості ключових діагностичних ознак цього виду і показано його досить виразну морфологічну однорідність. В межах західнопалеарктичних популяцій має місце виразна клінальна мінливість від відносно крупних південних і східних до дрібних північних і західних форм. Ареалогічний аналіз засвідчує наявність кількох відносно сильно ізольованих фрагментів ареалу, у тому числі виразний розрив ареалу між західними формами групи «тісrорs» (Центральна Європа, Балкани і прикарпатські регіони) та східними формами групи «иralensis» (від Придніпров'я і Прибалтії на схід до Уралу, включно з Кавказом і Малою Азією). Пропозиції щодо визнання видового рівня диференціації північних і південних форм та віднесення кавказьких форм (ciscaucasicus) до центральноєвропейських (microps), а кримських (baessleri) до верхньоволзьких (mosquensis) є надто гіпотетичними. Загалом наявні дані свідчать про наявність відмінностей між західними і східними формами Sylvaemus uralensis. Наведено детальні відомості про крайові знахідки двох груп популяцій — найбільш східні (північно-східні) знахідки групи «тісrops» та найбільш західні знахідки групи «uralensis». Між ними існує доволі значний розрив, що охоплює все ВолиноПоділля й Західне та Центральне Полісся, проте звужується на південь, в напрямку до Чорного моря. На півдні їні ареали, можливо, змикаються, проте верифіковані дані по суті демонструють розрив по всьому межиріччю між річками Дністер та Тилігул.

Ключові слова: гризуни, Sylvaemus, межі поширення, географічна мінливість, біогеографія, Європа.

Адреса для зв'язку: Ігор Загороднюк; Національний науково-природничий музей, НАН України; вул. Б. Хмельницького 15, Київ, 01030 Україна; e-mail: zoozag@ukr.net; orcid: 0000-0002-0523-133X 


\section{Theriologia Ukrainica, 20 (2020): 105-126}

Моделювання поширення вивірки звичайної (Sciurus vulgaris) в Східній Європі в умовах зміни клімату, згідно зі сценаріями нового покоління (SSP) до 2100 року. - Г. Коломицев, В. Придатко-Долін. - В Україні першу просторову модель поширення вивірки звичайної $S$. vulgaris з використанням генералізованого лінійного моделювання (до 2050 р.), GLM, в масштабах Східної Свропи, почали зужитковувати з 2008-2010 років на базі Центру менеджменту землі і ресурсів (ULRMC, Київ). Дане дослідження є продовженням, в якому використано основні релевантні сценарії зміни клімату МГЕЗК (ІРСС). Використано матеріали щодо поширення S. vulgaris (та S. anomalus) і асоційованих видів, а також банк кліматичних даних Worldclim (3 мапами і симуляціями 4-х релевантних сценаріїв до 2100 року). Моделювання показало, що за умов реалізації найбільш м'якого сценарію (із підвищенням середньої температури на $1.5^{\circ} \mathrm{C}$ ), зміна клімату може спричинити втрату $12 \%$ ареалу у Східній Європі і $49 \%$ ареалу в Україні. Симуляція другого сценарію (до $1.8^{\circ} \mathrm{C}$ ) - можливу втрату $14 \%$ і $57 \%$ ареалу, відповідно. Симуляції третього і четвертого сценаріїв (> $\left.2{ }^{\circ} \mathrm{C}\right)$, втрату $30 \%$ і $41 \%$ ареалу в межах Східної Європи, і втрату більш ніж 90 \% ареалу в Україні. Розуміючи, які колосальні втрати в екосистемах і біорізноманітті може спровокувати кожен відсоток таких змін, ми наголошуємо на необхідності встановлення та дотримання країнами найбільш амбітних зобов'язань із недопущення зміни клімату — це тих, які допоможуть втримати зміну середньої температури у межах $1.5^{\circ} \mathrm{C}$. Для порівняння, ми додали просторові моделі поширення інших видів до 2050 року, а саме дерев (дуб, бук, ялина, сосна, липа, береза - Quercus robur, Fagus sylvatica, Picea abies, Pinus silvestris, Tilia cordata, Betula spp.), а також куниці — Martes martes. У підсумку, до 2100 року, середовища існування вивірки звичайної, так само як і асоційованих видів, очікувано зміщуватимуться переважно «на північ»; локалітети із гірських територій Кавказу, вірогідно зазнаватимуть фрагментації. Скоріше за все, в природі такий тренд зміщення ареалу вивірки, який був отриманий нами із використанням імітації, реалізується не у вигляді прямої міграції особин саме «на північ», але через прояви синатропізації. Наскільки витривалим і задовільним для природнього відбору є цей механізм, залишається загадкою. Території, з яких історично походив і де був описаний підвид S. v. ukrainicus (Migulin, 1928), змінились докорінно: ландшафтно-екологічні втрати сягнули $>>50 \%$. До 2100 року суттеві зміни ареалів, вірогідно, демонструватимуть також бук і береза. Дослідження може бути використано освітянами - при викладанні історії науки, прикладної екології, заповідної справи, біотогеоінформатики. Присвячується Рокові вивірки (2020).

Ключові слова: вивірка руда євразійська, Sciurus vulgaris, SDM, WorldClim, SSP, RCP, Україна, Східна Європа, 2050, 2100.

Адреса для зв’язку: Григорій Коломицев; Інститут зоології ім. І. І. Шмальгаузена НАН України; вул. Б. Хмельницького 15, Київ, 01030 Україна; e-mail: gk@uncg.org.ua; orcid: https://orcid.org/0000-0002-07478600

\section{Theriologia Ukrainica, 20 (2020): 127-131}

Порівняння природної та реінтродукованої популяцій бабака степового (Marmota bobak) у Донецькій області (Україна). - С. Скубак. - Стаття містить відомості про поширення і чисельність бабака на території двох північних районів Донецької області - Слов'янського та Лиманського. Дослідження проводили у 2011-2020 роках. Загалом було обліковано 284 нори, що відносяться до 25 сімейних ділянок. Найбільші поселення бабака на дослідженій території нараховують 29 нір. Кількість нір на сімейних ділянках становить від 1 до 29 , середнє - 11,4. Загальна чисельність бабака складає понад 100 особин в Лиманському районі та понад 20 особин в Слов'янському районі. Слов'янська популяція $є$ реінтродукованою, в 1991 році випущено 370 ос. бабака. Лиманська популяція швидше за все має природне походження. Оптимальним біотопом для бабака $є$ крейдяні схили південної експозиції, де його сімейні ділянки містять найбільшу кількість нір. Постійні жилі нори розташовані в середній частині схилів, захисні нори в переважній більшості нижче по схилу та на дні балок. Всі поселення розташовані на правих берегах річок. Найбільші поселення бабака приурочені до бідних крейдяних та, рідше, піщаних грунтів з розрідженою рослинністю. Природна популяція бабака в Лиманському районі демонструє тенденцію до повільного розселення і зростання чисельності, в той час як чисельність реінтродукованої популяції набагато менше кількості випущених тварин. Щільність природної популяції лишається дуже низькою, є багато незаселених територій, придатних для бабака. Поселення мають груповий характер, суцільний ареал не сформований. Нові поселення бабака часто утворюються на місцях старих. Порівняно з реінтродукованими, природні популяції більш стійкі, щільність природної популяції бабака також вище. Найбільшу загрозу для бабака становить браконьєрство, особливо в Слов'янському районі. Другим за значенням фактором є заростання степу чагарниками через зменшення випасу. Поселення бабака на крейдяних степах майже нечутливі до зменшення випасу. В Лиманському районі зафіксований також негативний вплив пожеж і розорювання схилів балок. Епізоотії малоймовірні при такій дуже низькій щільності бабака. При належній охороні популяція бабака в регіоні може зберегтись та навіть розширити свій ареал.

Ключові слова: бабак, природна популяція, реінтродукована популяція, Донецька область.

Адреса для зв'язку: Є. Скубак; НПП «Святі Гори»; вул. Гутянська, 281, смт Ярова, Донецька обл. 84432, Україна; e-mail: nppsvyatygory@ gmail.com; orcid: 0000-0003-1144-4574 


\section{Theriologia Ukrainica, 20 (2020): 132-138}

Виявлення видів ссавців з прихованим способом життя методами лепідоптерологічних польових досліджень. - Ю. Геряк, С. Халаїм. - Наведено відомості про спостереження низки видів ссавців 3 прихованим способом життя та нічною активністю, зокрема вовчків, зроблені під час проведення польових лепідоптерологічних досліджень. Використання штучних джерел світла та ароматично-смакових принад у ентомологічних дослідженнях є одними 3 найрезультативніших методів, що забезпечують одержання багатої та різноманітної еколого-фауністичної інформації. Окрім лускокрилих, на світло та принади приваблюється багато інших безхребетних, насамперед, комах. Водночас великі скупчення безхребетних, що масово злітаються та збігаються на світло і принади, як легкодоступна їжа приваблюють низку ссавців із нічною активністю, здебільшого $з$ рядів комахоїдні (Soriciformes), кажани (Vespertilioniformes) та мишоподібні (Muriformes). Разом $з$ тим, до штучних джерел світла й ароматично-смакових принад приваблюються низка видів, які рідко трапляються та ведуть прихований спосіб життя, зокрема види родини вовчкових (Gliridae) - вовчок сірий, соня лісова та ліскулька руда. Останніх до світла, вочевидь, приваблюють комахи. Натомість, у випадку з використанням принад, для вовчків і мишака жовтогрудого ймовірно привабливим є саме їх аромат і смак, оскільки для них неодноразово відзначено живлення самою принадою. Водночас, яскраві джерела штучного світла, вочевидь, зацікавлюють й інших ссавців. Зокрема, в такий спосіб були відмічені: заєць, лис, сарна європейська, свиня дика, а також рідкісні: рись, кіт лісовий, тушкан великий і кандибка пустельна. На основі подібних спостережень, як приклад, наведено невеликий огляд нових знахідок вовчка лісового, зокрема в районах, де цей вид гризунів не відмічали, або відмічали вкрай нечасто. Авторами вид відмічений на пастках для лускокрилих у високогір'ї Українських Карпат (хр. Чорногора) та у Північному Причорномор'ї, в межах Одеської області. Таким чином, такі стандартні, часто використовувані у лепідоптерологічних дослідженнях, методи збору польового матеріалу, як приваблювання до штучних джерел світла та ароматично-смакових принад, можуть бути досить ефективними й у відношенні низки видів ссавців із різних таксономічних груп, зокрема прихованоживучих із нічною активністю.

Ключові слова: методи польових лепідоптерологічних досліджень, ссавці, прихованоживучі види, нові знахідки, вовчки.

Адреса для зв'язку: Юрій Геряк; Інститут екології Карпат НАН України, вул. Козельницька 4, м. Львів, 79026 Україна; e-mail: yu.ger@ukr.net orcid: 0000-0002-4446-403X

\section{Theriologia Ukrainica, 20 (2020): 139-149}

Особливості гніздобудування вивірки звичайної (Sciurus vulgaris) в умовах Кам'янця-Подільського. М. Д. Матвєєв, О. С. Бучацька. - Дослідження біотопного розподілу, чисельності та особливостей гніздобудування вивірки лісової (Sciurus vulgaris) проводилося з жовтня 2016 р. по травень 2017 р. на всій території м. Кам'янця-Подільського (Хмельницька область, Україна). За типом забудови та деревною рослинністю на території міста були виділені наступні біотопи: одноповерхової забудови, багатоповерхової забудови, змішаної забудови, паркова зона, промислова зона, Смотрицький каньйон, садово-городня зона. Було зареєстровано 272 гнізда (гайна) вивірки звичайної, зокрема, в парковій зоні - 89 гнізд (32,8 \% від загальної кількості гнізд); у промисловій зоні - 79 гнізд $(29,0 \%)$; у змішаній забудові - 49 гнізд $(18,0 \%)$; у багатоповерховій забудові - 19 гнізд (7,0\%); в одноповерховій забудові - 13 гнізд (4,8 \%); у садово-городній зоні - 12 гнізд $(4,4 \%)$; у Смотрицькому каньйоні - 11 гнізд $(4,0 \%)$. На території м. Кам'янця-Подільського було зареєстровано 178 гніздових територій вивірки лісової. Гнізда були зареєстровані на 21 видові дерев: липі Tilia sp., осиці Populus sp., гіркокаштані Aesculus hippocastanum, яворі Acer tataricum, клені польовому Acer campestre, в'язі Ulmus laevis, черешні Prunus sp., клені ясенолистому Acer negundo, ялині Picea sp., горісі волоському Juglans regia, грабі Carpinus beculus, вербі Salix alba, акації Robinia pseudoacacia, ясені Fraxinus excelsior, березі Betula sp., тополі Populus sp., тополі пірамідальній Populus pyramidalis, туї Thuja occidentalis, клені гостролистому Acer platanoides, гледичії Gleditsia triacanthos, дубі Quercus robur. Найбільше гнізд розташовано на тополі пірамідальній - 23,7 \% від загальної кількості гнізд, липі - 19,7 \%, клені гостролистому - 14,2 \%, а найменше на гіркокаштані - 0,7 \%, ялині - 0,8 \%. Вивірка лісова будує гнізда на висоті від 3,5 м до 23,0 м, середня висота розташування гнізда становить 9,3 м. Особливості розташування гнізда вивірки залежать від виду дерева (найвище свої гнізда вивірка будує на ясені, тополі пірамідальній, а найнижче на ялині і туї). У більшості випадків вивірка будує гнізда в мутовці, яка зазвичай складається з 3-4 гілок, - 50,7 \% від загальної кількості гнізд, а також біля стовбура - 34,9\%, на гілці - 12,2 \% і між стовбурами дерев - 2,2 \%.

Ключові слова: вивірка лісова, біотопи, чисельність, гайно, Кам'янець-Подільський.

Адреса для зв'язку: Микола Матвєє; Кам'янець-Подільський національний університет ім. Івана Огієнка; вул. Огієнка 61, м. Кам’янець-Подільський, 32300 Україна; e-mail: matveevmd@ukr.net, orcid: 0000-00019641-1653 


\section{Theriologia Ukrainica, 20 (2020): 150-157}

Рік вивірки 2020: огляд теми та подій. - Ю. Зізда, І. Загороднюк, С. Харчук. - Представлено огляд відомостей про вивірку як один з найпримітніших видів-символів. Із цим видом пов'язана величезна кількість етимологічних, фольклорних, історичних, символічних, природоохоронних і суто дослідницьких знань, ініціатив, досліджень. Саме тому вивірка стала одним з видів-символів, обраних Українським теріологічним товариством у циклі річних акцій «Роки звірят». Тому цей огляд значною мірою стосується заходів, пов'язаних з Роком Вивірки 2020 в Україні. Серед уже традиційних заходів, спрямованих на поширення знань, представлено цикл «21 найвідоміший факт» - добірку важливих і цікавих відомостей про вивірку, іiі біологічні та поведінкові особливості та іiі роль у житті людського суспільства. Розглянуто також інформацію про використання вивірки в символіці - маскоти, зображення на гербах різних міст, згадування у фольклорі та літературі, використання зображень в інших сферах. Наведено відомості про колірні форми виду, які можна розрізняти при знайомстві з вивірками, поширеними на теренах України. Окремо відмічено дослідження й проєкти стосовно вивірки, що проводяться в Україні та в суміжних країнах, включно з підготовкою наукових та студентських праць, шкільних проєктів та фотогалерей. Представлено відомості про етимологію та синоніми української назви «вивірка» та локації їх вживання. Вивірка як вид-символ 2020 року у діяльності Українського теріологічного товариства обрана і символом для логотипу 27 Теріологічної школи (Заліщики, школа відкладена через пандемію Ковіда). За сформованою традицією підготовлено галерею зображень вивірки, надісланих до Ради товариства українськими колегами, і найцікавіші 3 них, що відображають пластику виду та мінливість його забарвлення, наведено в цьому огляді. Зображення вивірки вміщено на обкладинці поточного тому наукових праць теріологічного товариства - Theriologia Ukrainica (том 20), а в самому томі вміщено дві наукові статті про цей вид та цей огляд подій, пов'язаних з Роком Вивірки в Україні (2020).

Ключові слова: вивірка, Рік Вивірки, види-символи, Теріологічна школа, природнича просвіта.

Адреса для зв'язку: Ігор Загороднюк; Національний науково-природничий музей, НАН України; вул. Б. Хмельницького 15, Київ, 01030 Україна; e-mail: zoozag@ukr.net; orcid: 0000-0002-0523-133Х 